\title{
STRENGTHENING DISTRICT HEALTH MANAGEMENT IN LOW-MIDDLE INCOME COUNTRIES: REFLECTIONS AND WAY FORWARD
}

\author{
Penguatan Pengelolaan Kesehatan Daerah di Negara Berpendapatan \\ Rendah-Menengah: Refleksi dan Langkah ke Depan \\ *Maye Abu Omar \\ Nuffield Centre for International Health and Development, University of Leeds, United Kingdom \\ ${ }^{*}$ Correspondence: m.a.omar@leeds.ac.uk
}

\begin{abstract}
Introduction: Health systems in low-middle income countries are undergoing considerable changes in a context of ongoing health sector reforms. Districts have, therefore, been increasingly recognised as the level where health policies and health sector reforms are interpreted and implemented. At the same time, decentralisation in its different forms has become a popular reform in many countries, and this increases the importance of ensuring that districts have the organisational capacity to offer a good service.

Aim: The article investigates the process, challenges and opportunities of health system development at district level in low-middle income countries.

Discussion: While district strengthening is probably necessary in relation to the success of all other health reforms, it is argued that it has not been accorded the importance probably because it is not seen as glamorous. The district health management team must include both strengthening the capacity of individuals, but crucially also, improvement of systems. Many initiatives have been patchy and fail to provide a consistent national approach. The persistence of top-down approaches to health care works directly against districts being able to take charge of their own affairs.

Conclusions: A shared vision of district strengthening must be achieved in order to progress with the achievement of Universal Health Coverage and Sustainable Development Goals.
\end{abstract}

Keywords: district health strengthening, capacity building, low-middle income countries, universal health coverage.

\section{ABSTRAK}

Lata Belakang: Sistem kesehatan di negara berpendapatan rendah dan menengah masih berubah-ubah dalam konteks reformasi sektor kesehatan yang terus berlangsung. Oleh karena itu, tingkat daerah semakin dikenal sebagai tempat interpretasi dan pelaksanaan kebijakan kesehatan dan reformasi bidang kesehatan. Hal yang sama juga berlaku pada bentuk-bentuk desentralisasi yang merupakan reformasi dikenal di banyak negara, dan sistem ini menunjukkan pentingnya memastikan daerah memiliki kapasitas managemen pelayanan yang bagus.

Tujuan: Artikel ini menelaah proses, tantangan, dan kesempatan pengembangan sistem kesehatan pada tingkat daerah di negara berpendapatan rendah dan menengah.

Diskusi: Penguatan daerah mungkin diperlukan untuk kelancaran reformasi pada semua lini kesehatan meskipun pada dasarnya daerah masih dipandang tidak penting. Tim manajemen kesehatan daerah perlu menguatkan kapasitas individual dan utamanya peningkatan sistem kesehatan. Banyak inisiatif gagal dan tidak merata dalam melaksanakan pendekatan nasional yang konsisten. Konsistensi pendekatan dari atas ke bawah pada pelayanan kesehatan dapat dilaksanakan secara langsung agar daerah dapat mengurus kepentingannya sendiri.

Kesimpulan: Visi penguatan daerah yang sama perlu diwujudkan untuk mencapai Universal Health Coverage dan Tujuan Pembangunan Berkelanjutan.

Kata Kunci: penguatan kesehatan daerah, pembangunan kapasitas, negara berpendapatan rendah dan menengah, universal health coverage. 


\section{INTRODUCTION}

Over the last three decades, many countries have developed health sector reform policies. In general, the intention is to improve the use of health care resources in the interest of the overall level of and accessibility to health care for the population to achieve universal health coverage (Berwick et al., 2006; Atun et al., 2015). The range of reforms undertaken varies from country to country, as does the extent to which the reforms are developed as a coherent policy response or picked up one at a time as a new fashions dictate, or as donor support when offered.

A comprehensive programme of reform requires changes of kinds at various levels of the system. Reforms at the systemic level include such measures as the development of a health financing strategy (frequently involving a user fees system or health insurance schemes, or both), development of a regulatory system or development of a sector-wide approach, or both (Senkubuge, Modisenyane, and Bishaw,., 2014; Frenk, 1994). Others are programmatic and set out what the health service does, for example, the development of a minimum health care package (Gidey et al., 2019). The lower level reforms (at the so-called organizational and instrumental levels) deal with how to provide the best mix of resources to provide services, the development of a data base, human resources and other inputs for health care.

A district has been increasingly recognised as the organisational level where health policies and health sector reforms are interpreted and implemented for actuating effective health care (Morgan, 2001). Increasingly, it is acknowledged that giving responsibility to districts has the potential to bring health care decision making closer to communities and more open to heeding community priorities (Liwanag and Wyss, 2019). Decentralization of health services has become an almost ubiquitous reform and a decision to be taken at the systemic level. In the whole policy and reform process, success or failure depends on the ability of district health managers to interpret and implement what is required.

Decentralizing functions without being accompanied by reinforcement of lower level management capacity can lead to de facto abandonment by the state system of those functions. Initiatives to decentralize authority can fail by inadequate management strengthening at the district level (Cobos Muñoz et al., 2017). Sumah, Baatiema, and Abimbola (2016) warn that decentralization to the district must not be taken "too far" in countries lacking effective local organizational structures and management skills. Collins and Green (1994) point out that decentralization can backfire in various ways, for example, by allowing locally dominant groups to snatch power and actually reduce popular participation, or by actually allowing central government to increase its powers through a centrally controlled local government system (Collins and Green, 1994).

This commentary article does not debate the different approaches to decentralization (Omar, 2002). However, it starts from the proposition that whatever a form of decentralization is adopted, districts need strengthening to be able to do their job and respond to challenges. It is assumed that they will require some ongoing support, both in terms of management expertise and in terms of technical expertise. The "district" looks very different in different countries in both organizational structure and size. The defining feature is that this is the organizational level closest to primary 
health care and the community (Shaikh and Rabbani, 2004). A strong and wellfunctioning district health system provides; a network of primary health care facilities that deliver a comprehensive range of promotive, preventive and curative health care services to a defined population with active participation of the community and under the supervision of a district hospital and district health management team; a network of organizations that provides or makes arrangements to provide, equitable, comprehensive and integrated health services to a defined population and accountable clinical and economic outcomes and health status of the population that it serves.

District strengthening is a reform at the organizational level. Perhaps for this reason, it is not seen as so attractive or important as the higher level reforms like other essential but non -"sexy" areas such as material support for improving provision of water, electricity and physical communications in health services. District strengthening is not the area that donors rush to be seen supporting nor the area that reformers merits their urgent attention in more than a token way.

At the same time, Ministries of Health in most of the low-middle countries all too often have a love affair with decentralization, but want to retain centrally all their old powers over operational matters. They fail to trust the districts to deliver health care as well as to make the necessary investment to strengthen them (Collins et al., 2007). This kind of decentralisation is unfortunate because the central ministries should rejoice in being freed of lower level considerations and excited about their new ability to focus on the systemic issues. Indeed, it constitutes a major error in thinking at the systemic level. This mistake is enough to render the whole worthless reform policy. On the side of districts, while there is a considerable anecdotal evidence that "learning by doing" is of vital importance in developing capacity to run services, it is also certain that newly autonomous district health teams need management strengthening (Collins et al., 2007).

lgnoring this need means ignoring the interconnectedness that exists between reforms, and that must be considered if a reform policy is not to be only a piecemeal collection of activities no more and indeed perhaps much less - than the sum of its parts. The ability of districts to deliver services is basic to many, perhaps all, reforms to be meaningful. For example, the Sector Wide Approach (SWAp) might be developed at a central level, but its elaboration at a district level can bring together the various health stakeholders. This requires a certain capacity and maturity within the district health team (Hill, 2002;Peters, Paina, and Schleimann, 2012). The logic of SWAp would further demand that systems strengthening efforts should be directed not only at government district health services but at all health care providers though the resource implications render a daunting prospect. Similarly, a health financing policy might be elaborated centrally but must be applied locally, and the capacity must be there to achieve this. The opposition to direct delivery of health services is seen as an important potential reform activity, but the possibility for inter or intra contracting district will only exist if the district health management team (DHMT) can sustain the process. Improved community participation is impossible unless the district can achieve it (McNee, 2012).

This article discusses the process, challenges and opportunities of health systems development at the district level in low-middle income countries. It also analyses the kinds of strengthening that are essential to the development of sustainable district management. Furthermore, it 
renders the requirements required to develop and sustain district management capacity.

\section{DISCUSSION}

\section{What are challenges and opportunities of health systems development at the district level?}

The preceding discussion demonstrates the complexity of health management strengthening at the district level. In tackling the issue, it is of great importance to find a comprehensive and integrated approach. Comprehensive refers to covering a whole country or at least a whole state, region or province. Some pre-conditions for successful management strengthening at a district level may be crucially determined at higher organisational levels, which are clearly of crucial importance to district viability. Many of the pre-conditions will only be possible if the central level is itself strengthened (Olum, 2014). These must address the shortcomings of the health system in its ability to support district management and directly improve both management systems and capabilities. Issues of sustainability must also be addressed. The implication is that district strengthening will only work if attempted as part of a wider coherent programme of health sector reforms.

At the same time, there are great advantages and opportunities in developing a homogeneous approach to district strengthening for a whole country (Omar, 2002). If districts operate on similar systems, they can provide mutual support more easily. Particularly in the initial stages of work that requires a major effort to support districts in developing systems and in providing other support, there are huge economies of scale to be achieved. It may be that the central ministry will be able to train a core team of trainers who will be available to provide ongoing training to district teams as well as supervision and support to their work (Hauck et al., 2019). This does not imply that all districts will progress at the same pace, or that strengthening has to happen in all simultaneously. However, it is hoped that all will move in the same direction.

On the other hand, integration in this context refers to the fact that there must be a plan for management strengthening activities, seen as part of a whole and located within any broader ongoing reforms. Many ministries of health in lowmiddle income countries have no plan as a basis for allocating resources or scheduling activities for training or management strengthening; while, others may have a formal training plan. This alone, however, misses the point that it is necessary to see district strengthening as a multi-faceted activity, tackling systems and capacity issues in a programmed manner (Hauck et al., 2019). Furthermore, for each activity of district strengthening, there needs to be some assurance of funding for implementation and later support and reinforcement. As pointed out by some authors, all too often these do not happen (Jaeger et al., 2018; Afrizal et al., 2019). Thought must, therefore, be given as to what approach to management learning is needed and then how to put that into operation. It is probably fair to say that current efforts on management strengthening have, in most countries, been patchy at best for some reasons.

\section{Partial approaches}

In practice, both governments and donors have often pursued partial solutions. For example, both may agree to allow a situation where some districts may be offered help from a donor, others not. Those offered support might receive it from different donors, pursuing a different approach. Indeed, most of us will have 
witnessed the sight of more than one donor in a single district where each donor resolutely pursues their own approach. The situation may be well-compounded by the presence of various non-governmental organisations (NGOs), which pursue their own path. Furthermore, many donors and NGOs come in with pre-conceived ideas about what is the magic bullet in district strengthening. They ignore the fact that often, a team exists and need to improve some capabilities, but somehow, they have been offering a service. Possibly, they will develop interventions that are inconsistent with the general socio-economic conditions and the cultural context. Some proposed approaches may even be inconsistent with the legal system in the country. Only too often, the resources available are wholly inadequate. The preceding discussion has adequately illustrated the scale and breadth of support required.

Partial approaches arise in other ways too. There seems to be a continued failure to learn the lesson of history that "model" or "pilot" district experiments are of dubious value. This could occur for some reasons. First, improving the performance of districts must include change and strengthening at the central level as well as at the district itself, but this rarely happens in an experiment with one or two districts (and arguably should not). Second, pilot experiments are notoriously difficult to replicate on a general scale; the most obvious problem at the stage of replication is that people wake up to the relatively intense use of resources in the pilot and realize that it cannot be afforded as a more general model.

\section{Top-down approaches}

Back in the 1970s, the Alma Ata Declaration saw a flowering of the concept of an integrated approach to primary health care that would take account of the intersectoral nature of ill-health and work to bring a positive approach to the struggle for good health for all. A little later, doubts were being expressed that this new approach was too expensive, but it was the basic actions proposed. Guardians and defendants of Alma Ata rose up to the defense of the original idea, and it seemed at that time, that debate had fairly conclusively knocked ideas of a selective or second-best approach to primary health care, well out of the window (Unger and Killingsworth, 1986). It is a sad reflection on the ability of the academic world to influence policy that things are in practice little changed and on how persistent these narrow and technocratic ideas have proved to be (Starling et al., 2002). The management burden of vertical programmes on top of trying to run a simple health service in a district is at least disruptive and has major implications on capacity and efficiency.

A related problem arises from the current fashion in developing Essential Health Packages (EHPs) for Universal Health Coverage (UHC). EHPs should be a great idea and the first pillar in district support as it is intended to define what resources are needed to provide an integrated set of health services appropriate to each level of care within a health service. Thus, it would be appropriate to expect the EHP to define the staffing levels and combinations for each organizational level and the levels of medical technology use and acquisition appropriate at each level. Thus, the EHP should set standards like what a few countries have done to be an invaluable yardstick against which districts can measure what they can offer.

In practice, however, more often EHPs are structured to prescribe that the primary level of care should treat ten diseases, a mere return to the selective approach. It is important to stress that any attempt to limit the EHP in this way is likely 
to be detrimental to community confidence in the health service, staff motivation, and actual results. Such top-down approaches limit districts rather than acting as an enabling tool and as such working against support.

International fashions are working further in creating new constraints. For example, the newly established global health fund that focuses on three major diseases that burden many poor countries, i.e. HIV/AIDS, malaria and TB, is intended to draw attention to and seriously address the problems (Selgelid, 2007; Brugha and Walt, 2001). However, due to the time-limit to the international commitment of the new alliance, poor countries, which alter their drug policies to incorporate expensive new drugs, could be left with additional unsustainable costs in the future. The fund was claimed to address the three diseases in ways that will contribute to strengthening health systems. Not all strategies to fight the three targeted diseases rely on health services for their implementation, i.e. promoting use of condoms or impregnated bed nets, but most do. Thus, case management is a particularly large commitment. A study shows that diverting resources from other activities to diseasespecific control programmes does indeed have the potential to weaken fragile health systems (Kruk et al., 2018). On the other hand, a study in Chad and Cameroon to assess Global Alliance for Vaccines and Immunization (GAVI) suggests that the delayed disbursement of funds, staff motivation and the lack of resources for doing routine and supervisory visits remain as major obstacles to strengthening the health system to carryout routine diagnostic, curative and preventive services (Dansereau et al., 2017).

\section{What kinds of strengthening are essential to the development of sustainable district management?}

Strengthening is likely necessary to ensure the district health system is viable. Of course, the form that decentralization takes in different countries will determine the precise capabilities the decentralized District Health Management Team (DHMT) will require. In some decentralized systems, for example, in Tanzania, districts may be responsible for running services, but have no responsibility for human resource management or procurement. In a devolved system, such as in Brazil, Pakistan and South Africa, these functions may fall to the provincial and local government officials. However, this article does not deal with questions of specialist expertise. The areas discussed in what follows are ones that the author believes will be needed in some degree by any DHMT as generic requirements. These will be examined in turn, asking what is needed to develop and strengthen district health management.

Pivotal to the effective running of health services is a team at a district level, working together to ensure services are delivered, sub-district facilities are supervised and so on. This implies that there will be open, transparent decisionmaking and that the whole team will have a say in decisions. While, individuals will have specific duties and responsibilities (Bonenberger et al., 2015).

It is obvious that team work is essential for the effective running of a district. Doubtless this view will find its critics, but it is the case that in most of low and middle income countries, a DHMT exists. It is also the case that often it is a team in little more than name only.

Lack of a team approach to working may have complex roots. In part, it may be that the management culture in the whole health service and more widely weighs 
against teamwork. Working conditions may be such that there is no incentive for staff to work together. Indeed, they may gain more by competing and playing one and another off against their bosses. Then, if staff have only ever experienced working under autocratic bosses who do not bother to explain or discuss anything, but simply give orders, they will find it hard to act differently. The first of these is possible to change by careful thinking about the structure and nature of incentives, and team-work training. The second is possible to change though it may be necessary to begin the change with facilitators coming completely outside the prevailing organizational culture. It may start with training for those trainers who will in turn train the district health officers or the managers and administrators, or both. However, the change will need to be followed through with consideration of the structure of delegation, staff appraisal, punishment and so on. If these left unmodified, they may fit the old system and constantly lead back to it.

One fairly standard feature of reform packages in different low-middle income countries has been in recognition that health services frequently need to take stock of the way they treat service users and increase responsiveness to, as well as collaboration with, the local community. The team should be able to develop appropriate means for the community to express community priorities and concerns for the health services. They should be responsive to offers of community participation in any aspects of the work (Doherty et al., 2018).

This item is also problematic. One cannot just tell people, in a simple lesson, how to be responsive to local communities. Most health workers are not trained to listen to lay people, other than to hear their symptoms of illness. They are not trained to respect communities in their expression of priorities for a health service. Indeed, it is argued both biomedical training and the hierarchical way in which medicine is practiced work directly against participatory approaches (Morgan, 2001).

A common development today is that health workers receive training, not in how to discuss or consult with communities, but rather how to assess user views through research. In a way, this is to distance the health team, not bring it nearer to the people. As some researchers are coming to conclude, time and resources spent on training staff and conducting interviews and focus group discussions may well be better directed towards training staff in engaging directly with communities in the consideration of their needs and priorities (Gishu et al., 2019).

One can envisage training health workers to listen better. This will, however, need to go along with several things; training health workers to help communities to express themselves more effectively; aiding them in creating some kinds of forum for joint discussion; and having skills to maintain that forum (Haver et al., 2015). Thus, only training will not suffice; there will also be a need for local systems development and perhaps creation of new local organizational structures or review of existing ones. On the whole, insufficient attention will have been given to the need for organizational development within statutory health care and other organizations if they are to embrace a partnership approach to services.

Nevertheless, two interesting examples in the late 90 s might be mentioned here. One is the Sheikupura Pilot Project in Pakistan, which has been studied in terms of its incomplete success (Tareen and Omar, 1998). Another is from the UK, where a group has been working to develop and try out the Strategic Action Plan for Healthy Communities (SAPHC) Model, which is essentially an approach to 
analyzing the need for capacity building in organizations wishing to engage more effectively with the public (Pickin et al., 2002). Unless consideration is given to the relationship between central planning and local needs, flexibility to consider the latter will not exist.

Next, this article would argue that the team needs to be capable of thinking strategically about the whole district. The degree to which this is important does depend on the modalities of decentralization. One would stress that some capacity to think strategically is needed in any district where a degree of decentralization has occurred. In some situations, devolution could lead to a situation whereby even some systemic issues (concerning equity for patients and or staff) may have to be handled at the district level.

It is important to have the capacity to think in broad terms about the overall health care being offered in the district, whether the approach optimizes use of resources, or whether future directions might be in some different ways. The team should be able to identify questions about existing health service delivery and to develop answers leading to change for improved practice. The team should also be able to plan and budget from broad strategies to making decisions about priority use of resources, as well as being able to cost activities and turn these into a budget.

The above needs deal with ability to observe, collect data, draw conclusions and ask questions. Many educational cultures around the world do not give priority to this range of skills at all. In many countries, health workers have reached a status of being relatively well-educated without having been challenged to draw their own conclusions from a set of observations. It is true they may have learned the narrow use of diagnostic skills, but diagnostic skills can be taught as use of memorized information with a little room for interpretation or creativity. Nor does such narrow questioning accustom people to thinking about the implications of their questions and observations for change. An interesting example comes from Haryana State in India, where data on health service delivery were analyzed locally and thus enabled planners to identify local needs and lobby for more resources at a higher level (Sharma, Prinja, and Aggarwal, 2017).

Analytical skills are difficult to impart, and are again only worth imparting in a management environment where they are of use. Only too often, we see health systems (and other systems, of course) where innovation and management improvements are not rewarded. Keeping quiet and maintaining the status-quo are what is rewarded in old-fashioned administrative systems, but such systems are hopelessly inadequate for running a district. If we can see some hopes of moving forward to a management system based on a learning process approach, we can help people to ask questions and teach them how to tackle issues and solve problems (Cox, 2001). Once officers see that change is possible, they will often be receptive to this.

Planning and budgeting depend on methods that can be taught, and systems can be imparted to districts through training and documentation. Arguably however, good planning (and there follows, budgeting) depends on the above mentioned processes being effective. Foster et al. (2000) make an interesting point about planning; they suggest that part of the capacity problem in health care may actually be a reflection of over-ambitious planning. Citing the example of Tanzania, they comment that "a culture of decision by consensus" makes it hard for anyone to say no to anything, and thus plans become 
over-ambitious (Foster et al., 2000). It is relatively easy to create a "wish-list" of activities and achievements. What requires real determination and dedicated efforts at consensus building is the setting of a focused list of priorities. It may be that formal methods support the transparent setting of priorities in a politically acceptable way (Thunhurst, 2003). This is the heart of the planning process in the famous words of late Julius Nyerere, "to plan is to choose".

Last but by no means least, planning involves implementation. This requires management and monitoring systems, as well as skills in delegation of work, conducting of meetings, and so on. A priority will be to ensure that management systems are in place. Much is required of the DHMT.

It is difficult to imagine a situation in which any degree of decentralization has taken place, that does not demand some financial management responsibility from the DHMT. The team needs to be able to handle resources responsibly and account for their use.

Accountability for use of resources depends on financial management skills, but these must go hand in hand with an effective and transparent system and with appropriate safeguards against corruption. However, Foster et al. (2000) suggest that one may only be able to strengthen district financial management systems by taking the risk of using them. Of course, this would need to go with some regular monitoring, evaluation and control (Foster et al., 2000).

DHMTs need to be able to monitor quality of care and provide supervision. These aspects are where adequate work from the centre can provide districts with good, simple and workable systems for quality assurance (including standards definition) and supervisory systems (Bradley et al., 2013). There will, however, be an ongoing need for support for districts in these aspects including provision for training (whether as first level courses or as in-service training).

These remaining items on the list are features that do not necessarily exist at all, nor have yet been encouraged in districts in many parts of low-middle income countries. Inter-sectoral collaboration has of course been on the World Health Organization's (WHO) agenda since the Alma-Ata declaration on Primary Health Care in 1978, but the practical manifestations of the idea are still not numerous (Adeleye and Ofili, 2010). However, it is clear that the potential for improving on intersectoral collaboration is probably much enhanced in a decentralized system. Collaboration with other health providers is an obvious step for district health management to take in today's world, where few countries envisage only provision of services as the way ahead. In many situations, a prerequisite for this would be the need for development of a system for the registration of NGOs (at both central and district levels) and the regulation of their activity. Lastly, a new demand on districts may be that management will need increasingly to be able to seek help for itself by commissioning services (Balogh, 1996; Checkland et al., 2018). In each case, the district needs to know about how one must specify what is required and the terms on which it might be bought, how to ask for estimates, and so on. New demands necessitate new capabilities. In all the last three items, the capability that is key to success is probably communication (Perrot, Carrin, and Sergent, 1997).

\section{What is needed to develop and sustain management capacity in districts?}

While strengthening district systems and capabilities might be seen as a one-off investment, support to districts needs to be ongoing. Support is not only that provided 
directly, but also for the creation of the necessary conditions for effective functioning of districts. Some of these are likely to be determined at a higher organizational level, perhaps at the central ministry level, or central government level.

Conditions for effective functioning include, for example, a degree of political stability. This is needed to ensure that the goals are not altered constantly and to allow ongoing development of a strategic vision, but only central government can offer this. Conditions in the districts themselves are obviously also of great importance. There are complex issues concerning the transfer of power to the districts, the quality of leadership in local government if local government exists, and the seriousness with which central government has promoted decentralization.

It may be, however, that local government will need education about the way the health sector works. Tang and Bloom (2000) describe the most interesting example of the way in which devolution has led to a reduction in the quality of health services in China. One of the main purposes of devolution is to encourage township governments to increase their funding. However, the government's grant in total health care decreased, and health centre managers reported that devolution led to increased financial insecurity. Furthermore, township governments asked local public institutions to do additional nonhealth related tasks. The government then threatened to withhold its health center grant unless these tasks were carried out. The health center manager had to comply with the detriment of service provision.

Districts also need to have some confidence that suitably qualified staff will be available when vacancies need to be filled. In part, this is to do with production of newly trained staff, but it also has to do with terms and conditions of service (Martineau et al., 2018). The latter affects both staff performance and ability to work in a team, and also staff retention. There are potentially strong arguments for national uniformity in human resource management, just as there are strong arguments for national definition of accepted standards of health care. However, there is an important set of considerations here concerning decision space (Roman, Cleary, and Mclntyre, 2017). The more the centre controls the way in which staff are treated, hired and fired, the less flexibility does the district have in its overall management. However, the centre then has a responsibility for ensuring that the interests of districts are served in the way things are done. On the other hand, if districts are given autonomy in the way they treat staff, the centre may need to retain some means of intervention to ensure equity in the distribution of human resources between districts.

A bottom-line pre-requisite of sustainability is the assurance of continued availability of resources to the district team so as to make planning possible. Crucially, there must be not only resources available for district operations, but also resources to support and strengthen them unless central and provincial government levels are prepared to set aside or solicit such resources and develop support arrangements appropriate to the extent and form of decentralization, management strengthening is an idle talk ( Collins, Omar and Tarin, 2002).

At the district level, the priority in strengthening management will be to ensure that there are well-developed district management systems in place. These should involve reproducible procedures, transparency and accountability. They should be backed by a well-developed collective memory, whereby the procedures themselves are clearly documented, and there are 
organized records that are routinely maintained. Let us not take this point too lightly. Often, there is little understanding of what is involved in the development, introduction and adoption of new systems. Management systems that work are unlikely to be available "off the peg"; one cannot assume that what works in India will go down well in Somalia, for instance. New systems have to be tried out in a particular social, political and economic context.

If change is brought in from outside, all too often the innovators see themselves as being helpful by making a mere technical innovation. Yet to the staff having to implement the use of the new system, this may not seem like a mere technical innovation; rather, it is an organizational change, an important change in the way they work (Bamberger et al., 2012; Mathauer and Imhoff, 2006). Such change needs to be introduced in a managed way with due consideration of the impact on individuals and their existing ways of doing things.

It is also important to consider that not everyone wants management systems to improve. Better management systems mean better accountability and much greater transparency. These will not be seen as positive goals by all. If the intention is to make them to become positive goals, then considerable attention will have to be given both to advocacy (for the new system) and also review of staff incentives and appraisal systems.

Alongside systems, the need is for a team with a relevant mix of capabilities, knowledge and experience (Prashanth et al., 2014). As noted earlier, there needs to be a management culture that sees innovation and improvement as a positive aim is required (Walker, Damanpour, and Devece, 2010). The range of activities that might support these things includes alongside systems strengthening, a whole range of learning opportunities, such as a formal training. In what follows, the article discusses issues concerning training at some length. It is important to stress the fact training is not seen as more important than systems development. The two are if anything, complementary requirements. However, individual performance may not necessarily improve as a result of skill and technology transfer through training activities (Irimu et al., 2014). Training is discussed because many people leap into perfunctory training activities in the name of district strengthening without acknowledging the problematic nature of some aspects of training.

It is a statutory fact that staff who benefit most from training especially long academic courses are the first to be lost to the government health sector. Where possible therefore, every effort should be made to ensure that district health management teams are well-defined, and jobs are described in such a way that adequately prepared professionals are recruited. In particular, more willingness to recruit professionals with management training and experience would provide an easier route to increasing capability than endless short courses. Perhaps if staff have to help themselves more to find ways to fund training, but then were rewarded with worthwhile jobs and good salaries, things would improve in this respect. It is possible that donors should be more open to salary support as a form of aid. This would, of course, have to go along with performance assessment.

When people think about district strengthening, they often think about formal training, and this certainly has its place. For instance, there may be special training opportunities created because of decentralization and the need for new skills. This might demand in-service training for the whole teams or particular officers in the teams. One or more team members might actually mount some such 
training for their colleagues. However, there are dangers. In many low-middle income countries today, a short-term training has become the scourge of district health work. As donors continue to ply short course and workshop participants with allowances, district staff are frequently lured away from the workplace for an unacceptably high proportion of their time. Not for nothing did the former Ugandan Minister of Health refer to the District Missing Officer. Various agencies compete to provide a training linked to different vertical programmes, new initiatives and so on. Rarely is there any consideration given to the overall effect.

One approach to this problem would be the development at the central level, of a system and capacity to control and regulate the training being offered to districts. The objective would be first to reduce duplication and ensure that training is at a level that is compatible with reliable and adequate service delivery. This central regulation would have to be strong enough to regulate competition between donors, daily allowances and so on. In the longer term, the responsible unit should be accountable for the continuous updates of first-level curricula for health professionals so that training, including some management training, is integrated and delivered in the most efficient way possible.

Training is, however, just one kind of learning opportunities. Other forms of learning take place through support and advice. One approach would involve having expert advisers to work alongside the district team over a period of time in a combination of systems development and action learning. Other learning opportunities might include advice offered during supervision or management audit, learning from each other, peer review between neighboring district teams based on structured observation of performance on the job. Yet, more important possibilities include informal inter-district support and exchange of ideas.

One should not overlook the potential support to be offered by the printed word or the computer. These may seem weak forms of support, but they have a great advantage that they can back up selfsupported learning and become the most effective of all means of learning. A district management manual exists in some countries, and this can be an invaluable resource. It provides an essential reference to district procedures, to important reference materials likely to be required by the district team, and to perhaps some information on relevant legislation. The centre can help to produce such manuals, but it would be hoped that the district would wish to also incorporate local materials. The manual might also provide guidance to support the district team in developing its own policies in specific areas, along lines suggested elsewhere (Heerdegen et al., 2020).

A library is also valuable at least to provide some essential references, especially in places where internet is not reliable (Mouhouelo et al., 2006). Books (and tapes and film if equipment is available) can be circulated around the district to maximize their use. The central ministry may be able to lend more books on a rotating basis. If the central ministry is so organized and if districts have computers, the possibility also will exist to offer an online information service to districts, as well as, of course, to allow Internet access.

The complementary approach to all of the above is to work on ways to encourage district staff to want to improve themselves. Important and essential means of motivating staff to improve lies in the development of a good monitoring system for district performance Reeve, Humphreys, and Wakerman, 2015). Not only should such a system be developed, but also careful thought needs to be given 
to its use. Of course, monitoring is not only carried out to track staff performance. However, this is one of its uses and a considerable potential to improve the accountability of district staff. One simple way to use the results of district monitoring (given that in many countries, a staff appraisal system as such simply does not exist) would be to base an assessment of team performance on it. If the team as a whole performed well, there may be a scope for some sort of rewards for them. Provided the rewards were substantial enough to be meaningful, such an approach would have the virtues of being simple and also of encouraging teamwork. This is not the only approach, however, and one might consider, in an appropriate setting, a more fully developed staff appraisal system for individuals to be desirable.

It is also important to consider to whom monitoring information should go and who should have a say in judging performance. An obvious answer is central government or, in a devolved system, the local government. However, alternatives should be carefully considered. One possibility would be peer-review, perhaps between analogous officers in different districts, not between officers who must relate together on a daily basis. Another possibility is to make the officers (or the team) increasingly more accountable to users and to representatives of civil society.

In the context of low-middle income countries, district management strengthening would to a large extent depend on well-equipped District Health Management Teams (DHMTs), who work at the interface between community and the health system. Figure 1 illustrates the hierarchical relationship of capacity development needs with human resources, i.e., DHMT (Cometto et al., 2020).

This requires appropriate governance and leadership that ensure sound policy (system level), clarity of roles and responsibilities that lead to effective accountability, supervision and management (organization level), which ultimately results in competent and motivated DHMT having expertise and skills (individual level) to effectively manage the districts.

Efforts need to be made to replicate adaptable practices that may exist in other districts with good performance. Considering the urgency of the situation, it is desirable to undertake a rapid assessment of performance by DHMT to identify model districts to draw lessons on the best practices that can be shared with other districts.

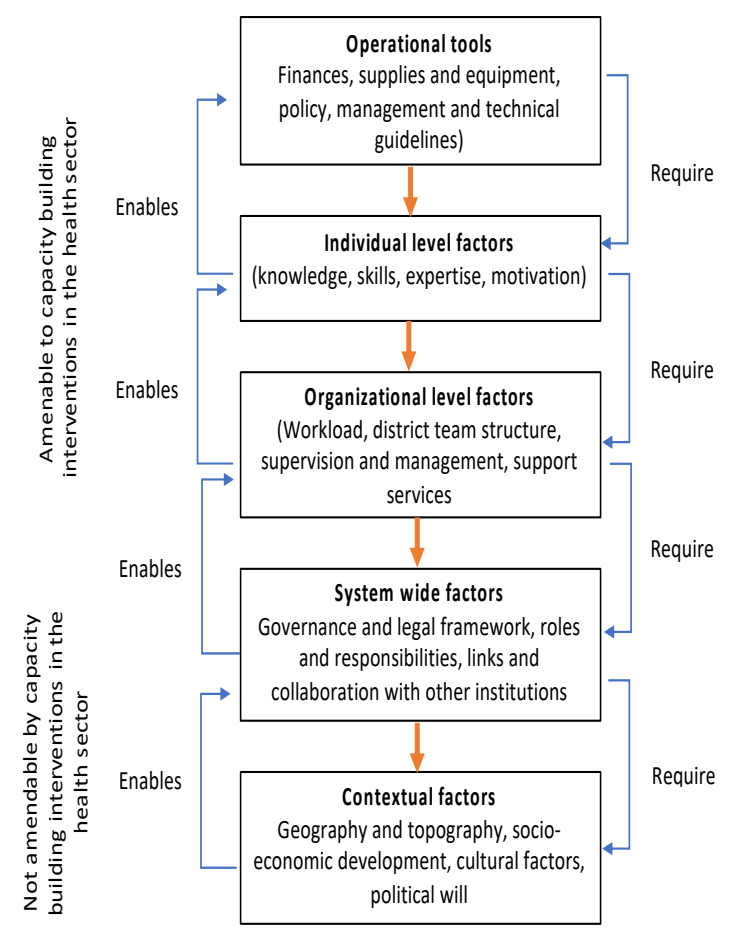

Figure 1. Hierarchical Relationship of Effective District Management Strengthening. Adapted from Cometto, et. Al (2020, p12)

Additional requirements for management strengthening of district health systems include political aspects and financial considerations that require working and collaborating with other non- 
health sectors and local community. These underscore the importance of strong leadership of the DHMT to mobilize the necessary support and resources to develop and sustain the capacity of the district to provide better health services consistent with the goals of Universal Health Coverage.

\section{CONCLUSION}

In conclusion, this article demonstrated the need to consider and involve health stakeholders in all efforts aimed to enhance the initiatives regarding district management strengthening. As a priority, all efforts should be seeked to identify resources to undertake it. At stake are both health systems and the community's health.

In part, governments in low-middle income countries must take responsibility for the neglect of district strengthening. Therefore, ministries of health need to champion and take a lead in managing the kind of management strengthening approach needed. Perhaps the first job required is to create a "vision statement" or "capacity building plan" that is comprehensive and integrated.

Undoubtedly, a plan for district capacity building is developed and later followed by greater donor coordination than has been possible in the past. If all the funding that currently gets spent on piecemeal activities is channeled into joint activities that are planned collaboratively, the results might be impressive. For example, in Malawi, such joint activities have taken place in several areas of work. In planning and budgeting, several donors have made contributions of varying sizes to developing the district process and providing its ongoing support. Similarly, in Nepal, a number of donors have been working with the government to develop medium-term strategic plan for health at the central level and bottom-up planning exercise at the regional and district level. Although such efforts are labor-intensive for multilateral and bilateral donors including NGOs, all must agree the approach taken. However, these will doubtless contribute towards long term sustainability of district management development efforts.

On the other hand, the article has identified the need and importance to look beyond central government and donors in seeking resources for district health management strengthening in achieving Sustainable Development Goals (SDGs). One source of funds and support in a decentralized system could be from local government. Often local governments are keen to invest in physical facilities. Ideas and policies will need to be developed whereby this is only allowed if the local government concerned simultaneously puts aside funding for training the number of new staff that would be needed and demonstrates its budgetary commitment to meeting all new recurrent cost implications.

Districts need to be encouraged to meet, engage, consult and involve with other health care providers and wider groups of stakeholders. Likewise, associations of religious health providers might be approached with a view to further improving cost-effectiveness by joint efforts in district strengthening.

\section{CONFLICT OF INTEREST}

The authors state that there is no conflict of interest for this article. 


\section{REFERENCES}

Adeleye, O. A. and Ofili, A. N. (2010) 'Strengthening Intersectoral Collaboration for Primary Health Care in Developing Countries: Can the Health Sector Play Broader Roles?', Journal of Environmental and Public Health, pp. 1-6. doi: $10.1155 / 2010 / 272896$.

Afrizal, S. H. et al. (2019) 'Barriers and challenges to Primary Health Care Information System (PHCIS) adoption from health management perspective: A qualitative study', Informatics in Medicine Unlocked, 17, pp. 1-10. doi: 10.1016/j.imu.2019.100198.

Atun, R. et al. (2015) 'Health-system reform and universal health coverage in Latin America', The Lancet, 385(9974), pp.1230-1247. doi: 10.1016/S0140-6736(14)61646-9.

Balogh, R. (1996) 'Exploring the Role of Localities in Health Commissioning: A Review of the Literature', Social Policy \& Administration, 30(2), pp.99-113. doi: 10.1111/j.14679515.1996.tb00430.x.

Bamberger, S. G. et al. (2012) 'Impact of organisational change on mental health: a systematic review', Occupational and Environmental Medicine, 69(8), pp. 592-598. doi: 10.1136/oemed-2011-100381.

Berwick, D. M. et al. (2006) 'The 100000 Lives CampaignSetting a Goal and a Deadline for Improving Health Care Quality', JAMA, 295(3), pp.324-327. doi: 10.1001/jama.295.3.324.

Bonenberger, M. et al. (2015) 'What Do District Health Managers in Ghana Use Their Working Time for? A Case Study of Three Districts', PloS one, 10(6), pp. 1-15. doi: 10.1371/journal.pone.0130633.

Bradley, S. et al. (2013) 'District health managers' perceptions of supervision in Malawi and Tanzania', Human Resources for Health, 11(43), pp. 111. doi: 10.1186/1478-4491-11-43.

Brugha, R. and Walt, G. (2001) 'A global health fund: a leap of faith?', BMJ (Clinical research ed.), 323(7305), pp.152-154.

doi:

10.1136/bmj.323.7305.152.

Checkland, K. et al. (2018) 'Being Autonomous and Having Space in which to Act: Commissioning in the 'New NHS' in England', Journal of Social Policy, 47(2), pp.377-395. doi: $10.1017 /$ S0047279417000587.

Cobos Muñoz, D. et al. (2017) 'Decentralization of health systems in low and middle income countries: a systematic review', International Journal of Public Health, 62(2), pp.219-229. doi: 10.1007/s00038016-0872-2.

Collins, C. and Green, A. (1994) 'Decentralization and Primary Health Care: Some Negative Implications in Developing Countries', International Journal of Health Services, 24(3), pp.459-475. doi: 10.2190/G1XJPX06-1LVD-2FXQ.

Collins, C. et al. (2007) 'Health system decentralisation in Nepal: identifying the issues', J Health Organ Manag, 21(6), pp.535-45. doi: 10.1108/14777260710834328.

Collins, C. D., Omar, M. and Tarin, E. (2002) 'Decentralization, health care and policy process in the Punjab, Pakistan in the 1990s', The International Journal of Health Planning and Management, 17(2), pp. 123-146. doi: 10.1002/hpm.657.

Cometto, G., Buchan, J. and Dussault, G. (2020) 'Developing the health workforce for universal health coverage', Bulletin World Health Organization, 98, pp. 109-116.

Cox, E. O. (2001) 'Community Practice Issues in the 21st Century', Journal of Community Practice, 9(1), pp.37-55. doi: 10.1300/J125v09n01_03.

Dansereau, E. et al. (2017) 'Challenges to implementing Gavi's health system strengthening support in Chad and Cameroon: results from a mixedmethods evaluation', Globalization and health, 13(83), pp. 1-12. doi: 10.1186/s12992-017-0310-0.

Doherty, T. et al. (2018) 'Role of district health management teams in child health strategies', BMJ, 362(k2823), pp. 1-5. doi: 10.1136/bmj.k2823. 
Foster, M. et al. (2000) The Status of Sector - Wide Approaches Centre for Aid and Public Expenditure (CAPE). London.

Frenk, J. (1994) 'Dimensions of health system reform', Health Policy, 27(1), pp.19-34. doi: 10.1016/01688510(94)90155-4

Gidey, M. T. et al. (2019) 'Willingness to pay for social health insurance and its determinants among public servants in Mekelle City, Northern Ethiopia: a mixed methods study', BMC Cost Effectiveness and Resource Allocation, 17(2), pp. 1-11. doi: 10.1186/s12962-019-0171-x.

Gishu, T., Weldetsadik, A. Y. and Tekleab, A. M. (2019) 'Patients' perception of quality of nursing care; a tertiary center experience from Ethiopia', BMC Nursing, 18(37), pp. 1-6. doi: 10.1186/s12912-019-0361-z.

Hauck, K. et al. (2019) 'How can we evaluate the cost-effectiveness of health system strengthening? A typology and illustrations', Social science \& medicine (1982), 220, pp.141-149. doi: 10.1016/j.socscimed.2018.10.030.

Haver, J. et al. (2015) 'Experiences engaging community health workers to provide maternal and newborn health services: Implementation of four programs', International Journal of Gynecology \& Obstetrics, 130, pp.S32-S39.

doi: 10.1016/j.ijgo.2015.03.006.

Heerdegen, A. C. S. et al. (2020) 'Managerial capacity among district health managers and its association with district performance: A comparative descriptive study of six districts in the Eastern Region of Ghana', PLoS One, 15(1), pp. 1-18. doi: 10.1371/journal.pone.0227974.

Hill, P. S. (2002) 'The rhetoric of sectorwide approaches for health development', Soc Sci Med, 54(11), pp.1725-37. doi: 10.1016/s02779536(01)00340-9.

Irimu, G. W. et al. (2014) 'Factors influencing performance of health workers in the management of seriously sick children at a Kenyan tertiary hospital--participatory action research', BMC health services research, 14(59), pp. 1-17. doi: 10.1186/1472-6963-14-59.

Jaeger, F. N. et al. (2018) 'Challenges and opportunities for healthcare workers in a rural district of Chad', $B M C$ Health Services Research, 18(7), pp. 1-11. doi: 10.1186/s12913-0172799-6.

Kruk, M. E. et al. (2018) 'High-quality health systems in the Sustainable Development Goals era: time for a revolution', Lancet Glob Health, 6(11), pp.e1196-e1252. doi: 10.1016/s2214-109x(18)30386-3.

Liwanag, H. J. and Wyss, K. (2019) 'Optimising decentralisation for the health sector by exploring the synergy of decision space, capacity and accountability: insights from the Philippines', Health Research Policy and Systems, 17(4), pp. 1-16. doi: 10.1186/s12961-018-0402-1.

Martineau, T. et al. (2018) 'Strengthening health district management competencies in Ghana, Tanzania and Uganda: lessons from using action research to improve health workforce performance', BMJ Global Health, 3(e000619), pp. 1-13. doi: 10.1136/bmjgh-2017-000619.

Mathauer, I. and Imhoff, I. (2006) 'Health worker motivation in Africa: the role of non-financial incentives and human resource management tools.', Human resources for health, 4(24), pp. 1-17. doi: 10.1186/1478-4491-424.

McNee, A. (2012) Rethinking Health Sector Wide Approaches Through the Lens of Aid Effectiveness. Australia. Available at: https://ssrn.com/abstract=2041830.

Morgan, L. M. (2001) 'Community participation in health: perpetual allure, persistent challenge', Health Policy and Planning, 16(3), pp.221230. doi: 10.1093/heapol/16.3.221.

Mouhouelo, P., Okessi, A. and Kabore, M.P. (2006) 'Where there is no Internet: delivering health information via the blue trunk libraries', PLOS Medicineedicine, 3(3), pp. 300-302. 
doi:

10.1371/journal.pmed.0030077.Olu

$\mathrm{m}$, Y. (2014) 'Decentralisation in developing countries: preconditions for successful implementation ', Commonwealth Journal of Local Governance, 15, pp.23-28. doi: 10.5130/cjlg.v0i0.4061.

Omar, M. (2002) 'Health Sector Decentralisation in Developing Countries: Unique or Universal!', World Hospitals and Health Services, 38(2), pp.24-30.

Perrot, J., Carrin, G. and Sergent, F. (1997) The contractual approach: new partnerships for health in developing countries. Geneva: World Health Organization.

Peters, D. H., Paina, L. and Schleimann, F. (2012) 'Sector-wide approaches (SWAps) in health: what have we learned?', Health Policy and Planning, 28(8), pp. 884-890. doi: 10.1093/heapol/czs128.

Pickin, C. et al. (2002) 'Developing a model to enhance the capacity of statutory organisations to engage with lay communities', J Health Serv Res Policy, 7(1), pp.34-42. doi: 10.1258/1355819021927656.

Prashanth, N. S. et al. (2014) 'Evaluation of Capacity-Building Program of District Health Managers in India: A Contextualized Theoretical Framework', Frontiers in Public Health, 2(89), pp. 1-14. doi: 10.3389/fpubh.2014.00089.

Reeve, C., Humphreys, J. and Wakerman, J. (2015) 'A comprehensive health service evaluation and monitoring framework', Evaluation and Program Planning, 53, pp. 91-98. doi: 10.1016/j.evalprogplan.2015.08.006.

Roman, T. E., Cleary, S. and Mclntyre, D. (2017) 'Exploring the Functioning of Decision Space: A Review of the Available Health Systems Literature', International Journal of Health Policy and Management, 6(7), pp. 365-376. doi: 10.15171/ijhpm.2017.26.

Selgelid, M. J. (2007) 'The importance of "throwing money at" the problem of global health', Indian J Med Ethics,
4(2), pp.73-5.

doi: 10.20529/ijme.2007.027.

Senkubuge, F., Modisenyane, M. and Bishaw, T. (2014) 'Strengthening health systems by health sector reforms', Global health action, $7(23568)$, pp. 1-7. doi: 10.3402/gha.v7.23568.

Shaikh, B. T. and Rabbani, F. (2004) 'The district health system: a challenge that remains', Eastern Mediterranean Health Journal, 10(1/2), pp. 206-214.

Sharma, A., Prinja, S. and Aggarwal, A. K. (2017) 'Measurement of health system performance at district level: A study protocol', Journal of public health research, 6(917), pp. 175183. doi: 10.4081/jphr.2017.917.

Starling, M. et al. (2002) New products into old Systems: The Global Alliance for Vaccines and Immunization (GAVI) from a country perspective. London: Save the Children.

Sumah, A. M., Baatiema, L. and Abimbola, S. (2016) 'The impacts of decentralisation on health-related equity: A systematic review of the evidence', Health Policy, 120(10), pp. 1183-1192. doi: 10.1016/j.healthpol.2016.09.003.

Tang, S. and Bloom, G. (2000) 'Decentralizing rural health services: a case study in China', The International Journal of Health Planning and Management, 15(3), pp.189-200. doi: 10.1002/10991751(200007/09)15:3<189::Aidhpm590>3.0.Co;2-q.

Tareen, E. U. and Omar, A. (1998) 'Practical Notes Empowerment at village level through a workshop method', Development in Practice, 8(2), $\quad$ pp.221-225. doi: $10.1080 / 09614529853846$.

Thunhurst, C. (2003) 'The use of problem structuring methods in strategic health planning', International Transactions in Operational Research, 10(4), pp.381-392. doi: 10.1111/1475-3995.00414.

Unger, J. P. and Killingsworth, J. R. (1986) 'Selective primary health care: a critical review of methods and results', Soc Sci Med, 22(10), 

doi: 10.20473/jaki.v8i2.2020.123-140

pp.1001-13. doi: 10.1016/02779536(86)90200-5

Walker, R. M., Damanpour, F. and Devece, C. A. (2010) 'Management Innovation and Organizational Performance:
The Mediating Effect of Performance Management', Journal of Public Administration Research and Theory, 21(2), pp. 367-386. doi: 10.1093/jopart/muq043 